Иванова В. А.

ИСТОРИЯ ПРАВОВОГО РЕГУЛИРОВАНИЯ ОСВОЕНИЯ НЕФТЕГАЗОВЫХ МЕСТОРОХДЕНИЙ АРКТИКИ В РОССИЙСКОЙ ИМПЕРИИ

\title{
Ivanova V.A. THE HISTORY OF LAW REGULATION OF ARCTIC OIL FIELDS DEVELOPMENT IN RUSSIAN EMPIRE
}

\begin{abstract}
Статья посвящена вопросам истории правового регулирования освоения месторождений Арктики в Российской империи. В статье описаны и проанализированы основные законодательные акты, регулирующие поиск и добычу нефти на нефтяных месторождениях Арктики в тот период, показаны этапы освоения первых месторождений нефти в российской Арктики.

Ключевые слова: Российская империя, право, история, Арктика, законодательство, горное законодательство, горная промышленность, нефть, Ухта, Ухтинское месторождение нефти, Новая Земля.

The article is about the history of law regulation of the Arctic oil fields development in Russian Empire. The main laws of that time on oil fields development in Russian Arctic are analyzed and the main periods of its development are described in the article.

Keywords: Russian Empire, law, history, Arctic, law regulation, mining regulation, mining industry, oil, Uhta, Uhta oil fields, Novaya Zemlya.
\end{abstract}

История нормативного становления горного права в России начинается с Указа Петра І от 24 августа 1700 года, которым был учрежден Приказ Рудокопных дел (Рудный приказ) для поиска «золотой, серебряной и медной, или иных каких руд» в рудоносных районах России. За время существования Рудного приказа было исследовано 121 месторождение рудных ископаемых в европейской части России. Он был упразднен 8 июня 1711 года, а его функции были переданы Сенату и местным губернаторам. Однако уже 15 мая 1715 года Рудный приказ был восстановлен по указанию Петра I под названием Рудная канцелярия, которая стала выполнять функции общероссийского органа по рудным делам, стала механизмом управления всей горной промышленности Российской империи. 13 марта 1718 года Рудная канцелярия была упразднена и ее функции переданы Берг-коллегии, которая была учреждена 10 декабря 1719 года Указом Перта I «Об учреждении Бергколлегиума для ведения в оном дел о рудах и минералах» (далее - Указ).

Берг-коллегия занималась вопросами металлургической промышленности, управлением монетными и денежными дворами, закупкой золота и серебра за границей, а также исполняла судебные функции. Для курирования этих вопросов по областям были созданы местные представительства Берг-коллегии. Одной из основных задач Берг-коллегии было освидетельствование нефтяных источников. В Указе подчеркивалось большое значение освоения месторождений, обладающих значительными запасами природных ресурсов. Государство поощряло поиск полезных ископаемых, в первую очередь, нефти. Берг-коллегия была вправе предоставлять предпринимателям льготные условия для поиска и раз- 
ведки природных ресурсов, частично освобождать от налогов для становления дела, освобождать числящихся в посадских людях и купцов от государственной службы.

Указом Петра I от 1719 года была установлена горная регалия, которая предусматривала исключительную государственную собственность на недра. Кроме того, данным Указом были определены основные принципы горной отрасли: государственная собственность на недра (горная регалия) и любая форма собственности на добытые природные ресурсы; отделение права собственности на землю и недра (принцип горной свободы); платность недропользования; рациональное освоение месторождений и охрана недр; свобода горного предпринимательства с ограничениями, касающихся отдельных видов полезных ископаемых (например, золота).

Таким образом, Указом была объявлена полная свобода поисков полезных ископаемых и горно-заводского промысла по всей стране как на казенных, так и на частновладельческих землях, с оплатой владельцу земли «тридцать второй доли от прибыли, без всякого удержания, и за прочие места, которые для того завода потребны вновь, также и за надлежащия дрова лес к строению, уплатить деньгами должны»; «каждому дается воля, какого б чина и достоинства ни был, во всех местах, как на собственных, так и на чужих землях, искать, плавить, варить и чистить всякие металлы, сиречь: золото, серебро, медь, олово, свинец, железо, також и минералы яко селитра, сера, купорос, квасцы и всяких красок потребные земли и каменья».

В соответствии с Указом государство предоставляло займы на строительство заводов: «кто в своих землях полезные металлы, яко золото, серебро и медь сыщет, и объявит в Берг-коллегиум, и похощет завод построить, тому дастся из коллегии, по доброте руд смотря, в займы денег настроение.» (п. 8). Налог в казну государства составлял «десятую долю от прибытка» (п. 11). В тоже время было возможно освобождение от его оплаты в случае, если убытки промышленника превышали его доход: «оную десятую часть на несколько лет отпустить, и тем пожаловать, ежеле при искании тех руд будет убытков больше прибыли.».

В функции Берг-коллегии также входило учреждение цен на металлы «по состоянию местоположений и иждивения». Также пунктами 12, 14, 15 Указа устанавливался порядок продажи добытых металлов - право покупки принадлежало го- сударству: «рудным начальникам, которые в близости тоя провинции к тому определяться, или кому из коллегии позволено будет». При этом согласно п. 14 в случае невозможности оплатить добытое по установленным ценам «промышленник оное волен продать, кому похочет». В соответствии с п. 16 права на построенные заводы при их надлежащем содержании предоставлялись промышленникам и их наследникам «по данным им привилегиям, или жалованным грамотам».

Таким образом, Берг-привилегия предоставляла право людям всякого звания искать и добывать полезные ископаемые даже на чужой земле, если ее владелец не занимался горным делом. Кроме того, в Берг-привилегии закреплялось следующее положение: недра принадлежат государству, а их эксплуатация возможна лишь путем концессии.

Так в 1745 году Берг-коллегия разрешила Ф.С. Прядунову открыть нефтяной промысел на реке Ухте с отсрочкой платежа десятины на два года. Нефть собиралась с поверхности реки Ухта, а для ее перегонки Ф.С. Прядунов построил перегонный куб, применявшийся ранее для получения дегтя и скипидара. Это был первый в истории нефтеперерабатывающий завод.

Ухтинское месторождение нефти расположено в Печорском крае в области Тиманского хребта в района реки Ухта. Согласно геологическим исследованиями Чернышева и Лебедева нефть залегает в девонской формации. Ухтинская нефть по свойствам схожа с Пенсильванской нефтью (США).

Ухтинская нефть была известна еще в 17 веке. Так голландец Н. Витсен в своем сочинении «Северная и Восточная Татария», вышедшем в 1692 году, упоминает, что река Ухта находится от Печоры на одни сутки и что на реке в расстоянии 1 1/2 мили от востока есть мелкое место, где из воды вытекает жир, представляющий нефть. При Петре I образцы ухтинской нефти направлялись в Голландию для исследования.

В начале 18 века был произведен ряд специальных исследований нефтяных источников на Ухте как государством, так и частными предпринимателями. В числе последних был московский купец Набатов, который с 1745 года уже добывал там нефть по несколько тысяч пудов ежегодно и вырабатывал из нее керосин. По другим источникам Набатов добывал черный каменноугольный деготь для лекарства, а для очистки дегтя у Набатова существовал завод.
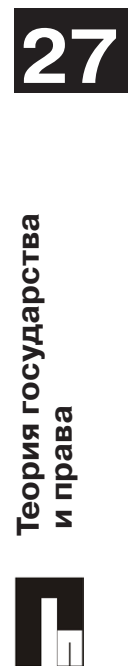
Добыча нефти на Ухте производилась Набатовым без всяких технических приспособлений. При этом Набатов добывал из этой нефти до 25\% керосина. Впоследствии примеру Набатова последовал архангельский гражданин Федор Прядунов, у которого в 1746 году был нефтяной завод.

Нефтяные месторождения на реке Ухте были описаны в записках академика Ивана Лепехина о его путешествиях в Архангельской губернии в 1772 году, в которых упоминается, что «в половине нынешнего век, гражданин Архангелогородского посада Федор Савельев сын Прядунов, ... сыскал нефть на Печере; производил сим земляным маслом торг ...».

Также упоминается первый нефтеперерабатывающий завод и разработка нефти на Ухте в описании Архангельской губернии в 1813 году Козьмы Молчанова. По его словам: «В окрестностях Ижмы на реке Ухте, впадающей в Ижму расстоянием от Ижимской слободки на 300 верст, был нефтяной завод, который состоял из следующего строения: над самым нефтяным ключом, на средине бьющим, построен был четвероугольный сруб вышиной в 13 рядов, из коих шесть были загружены на дно, а прочие находились на поверхности земли. Внутри сруба поставлен был узкодонный дщань, который истекающую из воды нефть впускал в себя отверстием дна; от быстротекущей воды защищал его поставленный с одной стороны водорез. От сего строения теперь никаких почти остатков нет, одна только нефть плавает по воде наподобие смолы».

Так в 1746 году на реке Ухте работал первый в России нефтяной завод Федора Прядунова для добычи нефти, которая сбывалась им в обеих столицах и за границу. Данный факт подтверждается определением Государственной Комерц Коллегии от 19 сентября 1758 года, согласно которому при Архангельском порту был назначен для брака нефти браковщик Архангелогородец Алексей Саванчаев.

Затем в 1753 году после смерти Прядунова этот завод перешел вологодскому купцу Андрею Нагавикову, в 1760 он во владения крестьянина Ивана Мингалева, затем к яренскому купцу Михаил БаженоBy.

Представляет интерес Указ Государственной Берг Коллегии от 1767 года № 834, в котором сообщаются сведения о нефтяных источниках, найденных Ратовым и Соболевым по течению речки Першай, в расстоянии примерно 200 верст от завода Баженова на реке Ухте. Нефтяные прииски в Пустоозерском уезде Архан- гельской губернии в пустых и незаселенных местах по рекам Ижме и Посве, впадающих в реку Печеру и нефтяные прииски на речках Чюте и Маниде, впадающих в реку Ижму были записаны за Ратовым и Соболевым Указом от 9 августа 1762 года. При этом в освобождении от уплаты десятины на десять лет им было отказано, так как «только от платежа десятины на десять лет уволены, кои на построение плотины и фабрик великой свой капитал употреблять, а как при добычи нефти, которая без всяких фабрик построения единственно черпанием достается...».

К концу 18 века всякая деятельность на реке Ухте по разработке нефти прекратилась.

Позднее принцип горной свободы был отменен Манифестом Екатерины Второй от 1782 года (далее - Манифест). Разведка и разработка полезных ископаемых стала возможна только на своей земле, разведка и разработка на чужих землях позволялась только по соглашению с собственником земли и с его разрешения.

Манифест отменил право исключительной государственной собственности на недра и установил право частной собственности на землю и ее недра. Согласно ст. 1 Манифеста «право собственности каждого в имении его распространяем и повелеваем разуметь не на одной поверхности земли ... но и в самых недрах той земли и в водах ему принадлежащих на все сокровенные минералы и произращения, и на все делаемые из того металлы».

Статья 2 Манифеста отменяла горную свободу, введенную при Петре I, и ограничивала поиск и добычу полезных ископаемых только на собственных землях, при этом статьей 3 давалось право освоения природных ресурсов на чужой земле на основании договора с собственником земли. Статья 4, статья 6 предусматривали возможность сбыта сырья на государственные заводы по договорной цене, либо свободную продажу сырья на рынке.

Статьей 8 устанавливалась ежегодная плата в размере десятой части дохода, полученной от реализации сырья.

Позднее положения, регулировавшие частный нефтяной промысел, были прописаны в Горном Уставе (VII т. Св. Зак., ст. ст. 541-615) и особых распоряжениях министра торговли и промышленности, которые разъясняли некоторые статьи Устава; затем Горный Устав был дополнен временными правилами от 13 мая 1900 года, которые регулировали вопросы предоставления некоторых участков заведомо нефтеносных земель без торгов для разведки и добычи нефти. 
Поиски и добыча нефти на землях в частной собственности лиц или обществ, а также приграничных к поссесионным заводам, разрешались владельцам таких земель или посторонним лицам по соглашению с владельцами земель (ст. 541 Горного Устава).

Освоение нефтяных месторождений было позволено лицам всех сословий, пользующихся гражданской правоспособностью с некоторыми ограничениями (ст. 547 Горного Устава). Так не могли заниматься добычей нефти лица, состоящие на государственной службе в горной промышленности в центральных и соответственных местных учреждениях, служащие в некоторых местных административных учреждениях, а также евреи, в местностях, где им было запрещено постоянное местожительство. Евреи, имеющие право жительства вне черты оседлости, иностранцы и иностранные общества, а также русские общества, имеющие акции на предъявителя, могли приобретать нефтеносные земли, искать нефть и получать отводы земель в Кавказском крае только с особого официального разрешения; кроме того евреи и иностранцы не могли управлять (на основании неограниченной доверенности) нефтеносными землями в Кавказском крае.

Все частные владельцы или общества были обязаны заявлять местному горному надзору об открытии месторождений нефти на собственных землях и о начале работ с указанием размеров участка добычи, а также кем будет разрабатываться месторождение (ст. 549 Горного Устава).

Местный горный надзор был обязан следить за соблюдением технических требований при добыче нефти на месторождении, установленных соответствующими правилами (ст. 550 Горного Устава).

В основном добыча нефти велась на государственных землях, поэтому особое значение имели правила закона, определяющие порядок пользования этими землями и разведкой нефти на них.

Поиски нефти на казенных землях, состоящие из поверхностного обзора и исследования местности без производства земляных работ, были позволены без особого разрешения и без ограничения пространства местности, подлежащей исследованию (ст. 557 Горного Устава); при исследовании глубоких слоев почвы (пробным бурением) для установления присутствия там нефти необходимо было получать разрешения, так называемые особые дозволительные свидетельства на двухгодичный срок.

За право разведок нефтяных место- рождений в Архангельской губернии, в Сибири, в Приамурском и Туркестанском краях и в областях Уральской, Тургайской, Акмолинской и Семипалатинской, как в малонаселенных местностях, была установлена плата в один рубль за каждую десятину, а во всех остальных губерниях и областях России - пять рублей с десятины. На разведываемой площади необходимо было устанавливать особый разведочный знак (обычно столб) с обозначением лица, производящего разведку (ст. 558 Горного Устава).

Выбор способа разведки нефти предоставлялся на усмотрение промышленника, но добытую нефть нельзя было вывозить за пределы разведочной площади (ст. 564 Горного Устава).

Промышленник, желающий добывать нефть в разведанной им местности, мог просить об отводе для своего участка в пределах разведочной площади (ст. 567 Горного Устава).

Просьба об отводе должна была быть заявлена надлежащему горному правлению не позднее срока, на который было выдано дозволительное свидетельство на разведку нефти. В просьбе указывался предполагаемый образ залегания нефти и породы, в которых она заключена, с приложением плана просимого отвода с обозначением места постановки столба и произведенных разведочных работ (ст. 568 Горного Устава).

При одобрении отвода горное управление публиковало в местных губернских ведомостях информацию об утвержденных отводах.

Размер и направление отвода предоставлялось так, чтобы:

1. Площадь отвода не превышала десяти десятин и была не менее одной десятины;

2. Отвод по возможности имел форму прямоугольника;

3. Ширина отвода была не менее одной трети его длины;

4. Остающиеся между отводами свободные площади были не менее одной десятины (ст. 571 Горного Устава).

Со дня выдачи дозволительного свидетельства на нефть такая местность признавалась занятой для разведок и другие промышленники не имели право производить поиски и ставить там столбы до объявления ее свободной для новых поисков и разведок.

За пользование отведенными под разработку нефти участками на государственных землях промышленники вносили в казну государства поземельную плату с каждой десятины, которая устанавли-

\section{9}

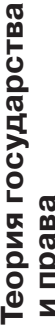


валась министром торговли и промышленности на двадцать лет (ст. 576 Горного Устава).

Если промышленник, получивший участок по заявке, не приступал к добыче нефти в течение двух лет, то участок объявлялся неразрабатываемым (тунележащим). Если же промышленник доказывал, что им затрачены средства на производство предварительных технических работ для добычи нефти, то ему давалась отсрочка еще на два года. Участок объявлялся также тунележащим в случае перерыва добычи нефти в течении четырех лет без уважительных причин. Тунележащие участки отдавались желающим добывать на них нефть в общем порядке (ст. 583, ст. 584 Горного Устава).

Поиски нефтяных источников на заведомо нефтеносных землях запрещались. Список таких земель составлялся Министерством торговли и промышленности и публиковался в Правительствующем сенате (ст. 581 Горного Устава).

По усмотрению министра торговли и промышленности государственная земля делилась на удобные для добычи нефти участки с размером не менее одной и не более десяти десятин каждый. Участки сдавались в разработку частным лицам на торгах (ст. 587 Горного Устава).

Нефтеносные участки сдавались на торгах по усмотрению министра торговли и промышленности за единовременный взнос или за попудную плату при условии обязательной наименьшей годовой добычи. В первом случае торг начинался с оценочной суммы, во втором с определенного размера попудной платы.

Если торги на получение каких-либо участков в аренду, назначенные три раза, объявлялись несостоявшимися по причинам неявки желающих, то такие участки могли быть отданы частным лицам без торгов за единовременный взнос или попудную плату по усмотрению министра государственных имуществ. При невозможности отдать участки для разработки нефти и без проведения торгов, такие земли могли быть обращены на другое назначение.

Среди недостатков действовавшего законодательства следует отметить следующее. Установленный на тот период порядок отдачи государственных земель частным лицам для добычи нефти создавал спекулятивное настроение и приводил к тому, что принятые на торгах обязательства внесения попудной платы не всегда выполнялись, так как такая плата оказывалась очень высокой. В связи с чем были введены особые временные правила для отдачи некоторых участков заведомонефтеносных земель без торгов для разведки и добычи нефти. Согласно этим правилам министр торговли и промышленности предоставлял участки государственной земли (как объявленные заведомо-нефтеносными, так и не объявленные таковыми) для разведки и добычи нефти без торгов. Выбором таких участков занималась особая комиссия при министерстве. Информация о предоставляемых участках публиковалось не менее двух раз в год. Соискатели должны были подать заявление и внести залог в 5000 рублей, который мог быть повышаем министром до 50000 рублей. Если оказывалось несколько соискателей, то между ними бросался жребий. Получивший участок обязан был приступить к правильному бурению в годичный срок и в течение первых трех лет провести буровые скважины, определенные договором. В случае обнаружения нефти в результате разведочных работ можно было получить отвод в 10 десятин в пределах разведанного участка на 24 года за подесятинную плату.

Тем не менее, временные правила не смогли решить проблему спекуляции с участками, что, в свою очередь, затрудняло расследование земель, объявленных заведомо-нефтеносными и приводило к повышению цены на нефть.

В связи с чем в 1908 году Государственная Дума отменила законопроект о продлении этих правил и постановила о внесении правительством нового законопроекта об отдаче государственных нефтеносных земель под разработку нефти на условиях, обеспечивающих нормальную добычу и доступность цен на нефтяные продукты.

Другой недостаток законодательства того периода был связан с правом государства объявлять определенные местности заведомо-нефтеносными. Прежде всего, объявление земель заведомо-нефтеносными исключало возможность дальнейшего поиска нефти и разработки таких земель, так как предполагалось, что нефтеностность уже установлена. Как отмечали исследователи того времени, такое решение иногда принималось на основании достаточно поверхностных исследований, а также приводило к тому, что частные поиски нефти на таких землях прекращались. Все это останавливало поиск нефти в таких районах и частные промышленники, которые брали в аренду такие участки заведомо-нефтеносной земли, несли риски не найти там нефти и понести значительные убытки из-за высокой арендной платы. 
Так район на р. Утхе был объявлен заведомо-нефтеносной землей. В связи с чем поиски нефти в нем были ограничены для частных предпринимателей, а желающих получить там участки на торгах и нести риски, связанные с поиском нефти и потерей вложений, не нашлось. По этой причине район вскоре отказался от признания земли заведомо-нефтеносной и был снова открыт для частных разведок. Как отмечают исследователи, иногда объявление земли заведомо-нефтеносной было юридическим установлением за ней свойств, которые с геологической точки зрения не были достаточно ясно установлены.

Затем в 1843 году ухтинскую нефть начал исследовать горный инженер граф Кейзерлинг, затем профессор Барбот-деМарни и инженер Романовский.

На их исследования обратил внимания известный деятель на севере Сидоров, который в 1860 году исследовал ухтинские месторождения и пытался приступить к их разработке. В результате ему удалось получить разрешение на разработку там нефти и им была заложена первая эксплуатационная буровая скважина.

Также Сидоровым вместе с Ольгой Рубцовой была организована экспедиция для поиска нефти и доманика на Новой Земле, в результате которой в 1873 году были получены семь образцов доманика, доказывающие присутствие горной смолы в трех местах: в двух на западном и одном на восточном берегах Новой Земли, одно в Малой Кармакульской губе, другое - в губе С. Анны и третье на заливе Литке, на противоположной стороне Кармакульскаго залива. На всех трех местах были размещены столбы с фамилией Рубцовой, что на основании нефтяного устава от 1 февраля 1872 года позволяло просить эти три участка под добычу нефти. Тем не менее, данные участки Рубцовой предоставлены не были.

В 1889 году приухтинский район снова был исследован в геологическом отношении специальной Тиманской экспедицией под руководством академика-геолога О.Н. Чернышева, результатом исследования которой ухтинский район был признан заведомо-нефтеносным. Вследствие этого дальнейшие исследования данного района были приостановлены и разработка нефти для частных предпринимателей запрещена.

В 1889 году инженер Гансберг подтвердил грандиозность запасов нефти на Ухте и убедил графа Канкрира основать предприятие для эксплуатации нефти в этом районе. Канкрир ежегодно уплачивал арендную плату, но никаких работ по разработки нефти им не предпринималось.

В 1906 году запрещение на разработку нефти на Ухте было снято и ухтинский район стал доступен для освоения частными предпринимателями. Тем не менее, работы были начаты только на трех промыслах генерал-лейтенантом Абаковским, капитаном Вороновым, «Северным нефтепромышленным товариществом А.Г. Гансберг и Ко». В разных местах ими были заложены более 20 пробных четырехдюймовых скважин, а Абаковым - шестидюймовая. Вслед за пробными скважинами, доказавшими наличие нефти, инженером Гансбергом была заложена скважина диаметром 17 дюймов. Тем не менее, с 1908 года Гансбергом было прекращено дальнейшее углубление скважины.

В тот период времени освоение Ухтинского района находилось в прямой зависимости от условий сбыта его нефти, так как Ухтинское месторождение не располагало необходимыми путями сообщения.

В 1908 году была организована особая экспедиция по определению возможных путей доставки нефти из Ухтинского района. Все предложения можно разделить на три группы: доставка железной дорогой, поставки нефтепроводом и доставка водным путем. Водные пути планировалось спроектировать на соединении с Архангельском, или Санкт-Петербургом, или Рыбинском, или Камой. При этом водные пути рассматривались как наименее выгодные, так как не были доступны для пользования в течение всего года. К началу 20-го века данный вопрос соединения Ухты с районами сбыта так и не был решен.

\section{Литература}

1. Берг-привилегия 1719 года «Об учреждении Берг-коллегиума для ведения в оном дел о рудах и минералах» // [Электронная ресурс]. Режим доступа: https://cyberleninka.ru/article/n/ukaz-1719-g-ob-uchrezhdenii-berg-kollegiumadlya-vedeniya-v-onom-del-o-rudah-i-mineralah/viewer

2. Фрадкин Н.Г. Академик И. И. Лепехин и его путешествия по России в 17681773 гг. // Н.Г. Фрадкин. 2-е изд. М.: Гос. изд-во географической лит., 1953. $218 \mathrm{c}$.

3. Описание Архангельской губернии, ее городов и достопримечательных мест 
со многим древними историческими известиями и замечаниями, к дополнению Российской истории служащими, из разных рукописных и печатных книг монастырских церковных архивов, из достоверных словесных преданий и других несомнительных источников, с приобщением Архангельской губернии карты, планы и вида города Архангельского, собранное в Архангельске (священником) Козмою Молчановым // СПб.: Главное Правление Училищ, 1813. 35-36 с.

4. Шидловский А.Ф. Исторические сведения о добывании нефти в Печорском крае // А.Ф. Ш-ий. Архангельск: Губ. тип., 1908. 15 с.

5. Манифест от 28 июня 1782 г. «О распространении права собственности владельцев на все произведения земли на поверхности и в недрах ее содержащиеся». // [Электронная ресурс]. Режим доступа: http://ivo.garant.ru/\#\%2Fdocum ent\%2F58105244\%2Fparagraph\%2F1\%3A0

6. Свод законов Российской империи. В 16 томах. Книга вторая. Том VII. Устав Горный. Глава IV. О частном нефтяном промысле. // [Электронный ресурс]. Pежим доступа: https://civil.consultant.ru/reprint/books/196/61.html\#img62

7. Сидоров М.К. Север России. О горных его богатствах и препятствиях к их разработке. // СПб.: тип. Почтового деп. 1870. 557 с.

\section{References}

1. Berg-privilegiya 1719 goda «Ob uchrezhdenii Berg-kollegiuma dlya vedeniya del o rudakh i mineralakh» // [Elektronnyy resurs]. Rezhim dostupa: https://cyberleninka. ru/article/n/ukaz-1719-g-ob-uchrezhdenii-berg-kollegiuma-dlya-vedeniya-v-onomdel-o-rudah-i-mineralah/viewer

2. Fradkin N.G. Akademik I. I. Lepekhin i yego puteshestviya po Rossii v 1768-1773 gg. // N.G. Fradkin. 2-ye izd. M .: Gos. izd-vo geograficheskoy lit., 1953. 218 s. 3. Opisaniye Arkhangel'skoy gubernii, yeye gorodov i dostoprimechatel'nostey s mnozhestvom drevnikh istoricheskikh pamyatnikov i zamechaniy, posvyashchennykh razlichnym rukopisnym i pechatnym knigam tserkovnykh arkhivov, dostovernym slovesnym predaniyam i drugim nesomnennym istochnikam, s priobshcheniyem arkhangel'skoy gubernii kart, plany i vidy goroda Arkhangel'skogo, sobrannoye $\checkmark$ Arkhangel'ske (svyashchennikom) Kozmoyu Molchanovym // SPb .: Glavnoye Pravleniye Uchilishch, 1813. 35-36 s.

4. Shidlovskiy A.F. Istoricheskiye svedeniya o dobyche nefti v Pechorskom kraye // A.F. SH-ii. Arkhangel'sk: Gub. tip., 1908. 15 s.

5. Manifest ot 28 iyunya $1782 \mathrm{~g}$. «O rasprostranenii prav sobstvennosti na vladel'tsev i drugikh lyudey». // [Elektronnaya resurs]. Rezhim dostupa: http://ivo.garant.ru/\# \%2Fdocument\%2F58105244\%2Fparagraph\%2F1\%3A0

6. Svod zakonov Rossiyskoy imperii. V 16 tomakh. Kniga vtoraya. Tom VII. Ustav Gornyy. Glava IV. O chastnom neftyanom promysle. // [Elektronnyy resurs]. Rezhim dostupa: https://civil.consultant.ru/reprint/books/196/61.html\#img62

7. Sidorov M.K. Sever Rossii. O gornykh yego bogatstvakh i prepyatstviyakh k ikh razrabotke. // SPb .: tip. Pochtovogo dep. $1870.557 \mathrm{~s}$.

ИВАНОВА Виктория Александровна, аспирант кафедры теории государства и права ФГБОУ ВО «Мурманский арктический государственный университет». 183038, г. Мурманск, Капитана Егорова ул., д. 15. E-mail: vnvvctr@mail.ru

IVANOVA Victoria Aleksandrovna, PhD student of FGBOU "Murmansk Arctic State University.". 183038, Murmansk, Kapitana Egorova str., 15. E-mail: vnvvctr@mail.ru 